Prima: Jurnal Pendidikan Matematika

Vol. 6, No. 1, January 2022, pp. 40 - 52

P-ISSN: 2579-9827, E-ISSN: 2580-2216

Web: http://jurnal.umt.ac.id/index.php/prima

\title{
LEARNING MEDIA PALANG AJIB (PAPAN LANGKA AJAIB) TO EASY IN UNDERSTANDING THE METERIALS OF RELATIONSHIP AND FUNCTIONS
}

\author{
Brenda Indah Nirmala ${ }^{1}$, Muhammad Ikhram An-Nurdin ${ }^{2}$, Muhamad Yafis Kahfi Muttaqin ${ }^{3}$, \\ Novi Aisy Fajriati ${ }^{4}$, Agus Miftakus Surur ${ }^{5}$ \\ Institut Agama Islam Negeri Kediri, Jln Wahid Hasyim no 62, Kediri, Indonesia \\ email: surur.math@gmail.com
}

\begin{abstract}
The teaching and learning process needs the media that plays a role in it. Decreased student understanding in learning results in decreased student learning outcomes. The media that is considered appropriate and in accordance with current conditions is the Palang Ajib learning media (Papan langka Ajaib). This media is used to teach in the classroom where the teacher usually only uses books and boards. The research method used is development research with the ADDIE model. The research begins with an analysis of the needs needed in the field, then continues with making appropriate media designs. The next step is to develop the media based on the designs that have been made. The next step is implementation and evaluation. By using this learning media, it is intended to make the learning process more effective and not boring. In addition, there is another purpose, namely this media is made to make it easier for students to learn and understand the material Relations and Functions. The process of making this learning media using materials and tools can be found in the surrounding environment. In addition, the benefits of this media make it easier for students to learn and understand Relations and Functions material, hone children's creativity, increase children's interest and enthusiasm in studying Relations and Functions material.
\end{abstract}

Keywords: Learning media, Benefits of learning media, Relationships and Functions, Palang ajib

\begin{abstract}
Abstrak
Proses belajar mengajar perlu adanya media yang ikut berperan didalamnya. Pemahaman siswa yang menurun dalam belajar mengakibatkan hasil belajar siswa juga menurun. Agar siswa tertarik dalam belajar maka dibuatlah inovasi media pembelajaran ini. Media yang dirasa tepat dan sesuai dengan kondisi saat ini adalah media pembelajaran Palang Ajib (Papan langka Ajaib). Media ini digunakan untuk mengajar di kelas yang biasanya guru menggunakan media buku dan papan saja. Metode penelitian yang digunakan adalah penelitian pengembangan dengan model ADDIE. Penelitian diawali dengan analisis kebutuhan yang dibutuhkan di lapangan, kemudian dilanjutkan dengan membuat desain media yang sesuai. Langkah berikutnya mengembangkan media tersebut berdasarkand desain yang sudah dibuat. Langkah berikutnya yaitu implementasi dan evaluasi. Dengan menggunakan media pembelajaran ini dimaksudkan agar dapat menciptakan proses belajar menjadi yang lebih efektif dan tidak membosankan. Selain itu ada tujuan lain yaitu mudia ini dibuat agar mempermudah siswa dalam mempelajari dan memahami materi Relasi dan Fungsi. Proses pembuatan media pembelajaran ini menggunakan bahan dan alatnya dapat ditemukan dilingkungan sekitar. Selain itu manfaat dari media ini mempermudah siswa dalam belajar dan memahami materi Relasi dan Fungsi, mengasah kreatifitas anak, meningkatkan minat dan semangat anak dalam mempelajari materi Relasi dan Fungsi.
\end{abstract}

Kata kunci: Media pembelajaran, Manfaat media pembelajaran, Relasi dan Fungsi, Palang Ajib

\section{INTRODUCTION}

Media is a word that comes from Latin, namely medium which means "an intermediary" or "introduction". Furthermore, the media is defined as a message or information from an information source that is channeled through intermediary means, which will be conveyed to 
the recipient (Surur, 2021). The use of learning media can help learning success. Danim emphasized that the results of many studies have proven the effectiveness of using aids or media in the teaching and learning process in the classroom, especially in terms of increasing student achievement. The limited media used in the classroom is said to be one of the causes of the weak quality of student learning. Thus, teaching and learning activities carried out in the classroom cannot ignore the need to use a media. The need for this media in the teaching and learning process is used in various activities experienced by students. The activity is to increase insight and knowledge as a preparation for life in the future. One of the efforts that must be achieved is how to create a learning experience that allows the learning process to occur in students by mobilizing all learning resources and effective and efficient ways of learning (Supriadi, 2015). In this case, learning media is one of the supporters in helping the learning process happen (Mahnun, 2012).

The role of learning media in the learning and teaching process is an educational unit that cannot be separated from the world. Learning media are everything that can be used to transmit messages to recipients, so that they can cause students' thoughts, feelings, concerns, and interests to learn (Aspar et al., 2020). Learning media is one of the teaching aids for teachers to deliver teaching materials, increase student creativity and increase student attention in the learning process (Tafonao, 2018). A good learning process will be intellectual, critical thinking, and bring out creativity and change one's behavior or personality. The learning process will not run smoothly, if there are no learning components which include teachers, students, learning materials, learning methods, and learning media. Carrying out teaching and learning activities without using learning media can run, but the success rate may not increase using learning media (Miftah, 2013).

In the process of delivering the Palang Ajib learning media, there are several problems. The problem is where the formation of a learning media, Palang Ajib, namely students' understanding of relational and functional concepts, there are mistakes made by students. Students have difficulty in receiving material on this Relations and Functions material, especially when given a question, usually in solving problems or problems there will be obstacles when drawing (Narulita \& Masduki, 2016). Draw a pie chart that makes students lazy to draw it because it takes a long time and sometimes students get bored in working because they have to draw pie charts over and over again, some students also have not been 
able to state the relationship correctly using pairs in sequence, determining the origin area, and result areas, as well as the use of inappropriate steps in solving problems (Surur et al., 2020). In addition, low-ability students are also unable to distinguish between relations and mapping, as well as not being able to draw a function.

With the Palang ajib (Papan Langka Ajaib) media, it makes it easier to solve existing problems, besides that it also doesn't take much time to just use the media for problem solving and also doesn't make you bored because it's interesting to do instead of drawing pie charts. first in the book (Tafonao, 2018). The Palang ajib (Papan Langka Ajaib) hopes to increase a sense of enthusiasm and interest in learning the material on Relations and Functions. Because many students see that it is difficult, they don't even understand about the material of relations and functions for reasons that are difficult, complicated, confusing. With complaints like this, media in the form of Palang ajib is made, where Palang ajib can facilitate the process of solving a problem that arises. In addition to simplifying the problem solving process, Palang ajib is also easy to use and not complicated. The materials used are also from materials that are around so that they can be recycled and are more useful and environmentally friendly. In addition to being environmentally friendly because it is around, it can be easily made without having to bother looking far for the materials to be used (Fauziah, 2013). In addition, there is also no need to spend a lot of money to make this Palang ajib media so that it does not burden students and teachers in spending costs. Because the important thing is to be able to facilitate learning activities by using this media, it doesn't matter if you use only makeshift materials as long as the objectives are conveyed.

\section{RESEARCH METHODS}

The research method used is the research and development method. This method is used by researchers to produce a product (Surur, 2020) in the form of a learning media called Palang ajib which will then be tested for the effectiveness of the media. The development research method is defined as a research method used to produce a particular product and then test it (Sugiyono, 2014). Development is a journey process from design specifications which are then translated into a concrete form (Richey \& Klein, 2007). This design is related to systematic learning design, development of learning media/models and product 
evaluation. The aim of this development is to improve existing media/methods (Hada et al., 2021).

The development model used is the ADDIE model. The ADDIE model is used as a systems approach used in media development. The special thing that exists in the ADDIE model is at the planning stage which is divided into several steps. The steps shown are logical Steps which are easy to implement. In addition, there are procedures for its use so that it is in accordance with the intended use of the media (Januszewski \& Molenda, 2008). The instruction process in the ADDIE model consists of several phases. There are five phases to follow in this instruction. These phases in sequence are needs analysis, design, product development, product implementation and overall evaluation (Cahyadi, 2019). In this media, it has reached the development stage, namely the media is ready to be used in learning.

At the analysis stage, the researcher collects some information from parties related to learning, namely teachers and students to obtain problems that occur in the field. The problem is then formulated several possibilities that can be taken to solve the problem, one of which is by holding a learning media. After the analysis process, the researcher designs the media that will be used. The design is made with attention to materials and tools that are easy to find and easy to obtain. After the tools and materials were obtained, the researcher made a media design to the media production stage. After the media has been created, the media is ready to be assessed by media experts.

The selected validators are colleagues who in teaching also use the media in some mathematics materials. The validated section covers how to create media, media a ppearance, media form, media color selection, readability of writing related to media, media durability, media reuse, media ease of use and media storage methods. The results of this validation will be used to revise the media so that it can be used in the next stage.

\section{RESULTS AND DISCUSSION}

\section{Mathematics Material with Palang ajib Media}

Media Palang ajib was created to facilitate the process of learning the material Relations and Functions learned in class VIII SMP. Functions and relations are part of mathematics lessons (Herawati, 2014), where these functions and relations are interconnected with one another. In many ways, the function is applied in various fields to solve problems both in the 
fields of engineering, economics and other fields that study the relationships between variables, where variables influence each other and can be measured, such as distance and time can be measured, so that It can be said that distance is a function of time. Within functions and relations, there is a place of origin, a friend's area, and a product area. The origin region is called the domain, the friend region is called the codomain, while the resulting region is called the range.

An element in set $A$ that is paired with elements in set $B$ through a certain rule is called a relation from set $A$ to set $B$. Meanwhile, an element in set $A$ that is paired with elements in set $B$ with exactly one pair using a special relation is called a function (mapping). Two terms that have similar definitions can be easily distinguished when studying using the Palang Ajib media.

\section{Characteristics of the Media Palang ajib}

The characteristics of the media on the Palang Ajib media that were made are:

1) Explanative characteristics

Learning media has explanatory characteristics, because learning media can clarify the presentation of learning material delivered orally by the teacher.

2) Distributive characteristics

Learning media should also be distributive, in the sense that learning media have the ability to reach large audiences in one presentation simultaneously.

3) Accessibility characteristics

The learning media used in the teaching and learning process should be accessible to both teachers and students as the target audience. Media accessibility depends on the technology used and the learning objectives themselves.

4) Manipulative characteristics

Learning media used in the learning process can be presented to a large number of students and the learning experience is relatively the same.

\section{The Role of the Media Palang ajib}

Learning objectives to be achieved in the world of education can use the facilities of a media that is functioned according to the rules. The involvement of students in using the media as a form of channeling information embedded in the media. Student involvement starts from thinking, to involving physical activity, so that learning can occur and can be 
observed. The design of the material to be delivered is more systematic according to the stages of learning, and psychologically adapted to the student's circumstances. Instructions for using media must also be observed, so that students are easy to use the media. The different character of students can be accommodated with the use of media that is fun and in accordance with the circumstances of the students. The roles of the Cross Ajib media are:

1) Smooth learning process, and improvement of learning outcomes in relation and function materials, with clear media presentation and clarity of information.

2) Students' attention can increase with the use of media, so that learning motivation appears, and interaction also increases between students and their environment.

3) The same experience can be given by a learning media about events in the student's environment, as well as interactions between fellow students and interactions with teachers.

\section{Relationship between Media and Mathematical Materials}

The essence of learning is a process, namely the process of setting the learning environment, and organizing it, so that the learning process can be carried out by students in a growing and developing way (Pane, 2017). Learning is also said to be a learning process carried out by students by guiding or providing assistance to achieve goals. The teacher acts as a mentor departing from the problems faced by students. In learning, of course, there are many differences, such as the presence of students who can quickly receive the information conveyed, there are also students who are slow in digesting the subject matter. These two differences cause learning strategies to be regulated by the teacher in overcoming problems by adjusting the circumstances of each student. Therefore, if change becomes the essence of learning, then the essence of learning is regulation (Muhammad, 2017).

Mathematics is an abstract subject. This makes learning media play an important role in the teaching and learning process of mathematics, so teachers need teaching aids or media so that the material presented becomes clearer and easier to accept. In this case, especially the material for geometric transformations contained in mathematics lessons. The use of media does not replace the role of the teacher in the classroom, nor does it mean to be a source of information, but the existence of learning media makes it a tool that helps streamline and streamline the teaching and learning process (Badriyah, 2015). 
Media Palang ajib in learning mathematics has the meaning of a board designed to form an arrangement of the completion process related to the material relations and functions. The purpose of making this media is to provide a brief description and explanation related to relation and function material, this media aims to attract students' interest in learning relation and function material in a fun way and give students the assumption that relation and function material is easy material in learning mathematics (Nurrita, 2018). In learning mathematics, the use of this media is expected to help overcome difficulties in understanding material related to relations and functions (Munirah, 2018), the process of learning activities takes place. With this media, students will get clear experience related to the process of completing relation and function material. This media has many advantages including the easy way of making it, the media can be used repeatedly in the following school year, can be used indoors or outdoors, very practical, this media packs learning creatively and innovatively, as well as the materials used for the manufacture of learning media is relatively cheap and easy to find.

\section{Steps / Stages of Making Palang ajib Media}

1) Preparing Tools and Materials

Regarding the tools and materials prepared, the materials and tools are easy to obtain because they are easy to find. The tools used in the form of pencils, ballpoint pens, markers, and scissors. While the materials that must be prepared are cardboard, bufalo paper, origami, sticks or skewers, and glue. As shown in the picture, the materials and tools used are not easy to find.

2) Making the Board for the Base

After preparing the tools and materials mentioned above, then make a base to put the media out of a rectangular cardboard with a size of $30 \times 45 \mathrm{~cm}$. If it is, then cover it with bufalo paper to make it look neat and attractive so that it is not visible if it is made of cardboard

3) Creating Domain and Codomain Fields

Cut the leftover cardboard to make the board in the shape of an oval, it can also be in the form of a circle or other interesting shapes. When it is finished, it is formed according to the pattern and cut using scissors or a cutter, it can be coated with bufalo paper to make it neat and attractive. Don't forget to distinguish the color of 
the bufalo paper between the board to place it and the area of the diagram. As in the picture the board uses green and the diagram area is yellow.

4) Create the Object Pointer

The object pointer is made of sticks wrapped in colorful paper. How to make it by preparing origami paper and sticks. The origami paper is cut lengthwise as shown in the picture and wrapped around a stick and glued using the existing paper glue so that it is neat and not exposed to the hands of the stick. In addition to safety in use by making it colorful, various makes it more interesting and easy to understand. The function of this object pointer is for arrows between domains and their codomains.

5) Create a Tool to Paste Domain Members and their Codomains In relation and function material, there are domains, codomains and ranges. Where domain is the area of origin. And codomain is friend area. While the range is the result area, therefore it requires a tool to paste the existing members in the domain and codomain. Can use a stick that is inserted into the plane of the diagram as shown in the picture.

6) Paste the Domain and Codomain Fields (diagram) on the Board for the Pedestal The board for the base made in the second step that has been coated with colored paper on top is pasted with the domain and codomain fields that have been made in the previous step which have been given the tools to paste the domain members and their codomains. The purpose of why the baseboard and the domain and codomain planes are so that the colors do not mix and can easily distinguish them. Can stick the plane on the board using glue. Don't forget to make it as real as possible.

7) Writing the Title on the Media Board

To make it clearer and more interesting, add a title at the top of the blank. You do this by sketching the letters on the back of the origami paper of different colors and when you have formed the "PALANG AJIB" writing pattern, you can cut it using scissors or a cutter. After you finish cutting, just stick it on the media board. Made in colorful colors to be interesting and not boring. And don't forget to write that shows that this is a relation and a function. In addition, each domain and codomain 
is given a description, for example, the domain is labeled $A$ and the codomain is labeled B.

8) Create a Domain Member and its Codomain

Fill in the domain members and codomains by cutting a different colored bufalo paper from the domain area with a length of $1 \mathrm{~cm}$. After cutting it into a rectangle, cut it again using square scissors measuring $1 \times 1$ and write the members on the square paper using colored markers.

9) Arrange Everything That Has Been Made In Order To Become A Media That Can Be Used

If in the previous step you created a tool to paste the existing members in each domain and their codomain and create a member field, now arrange them so that they can be used. For example, create a set in domain A whose members are in codomain $B$. For example Domain $A=1,2,3,4$, while $B=1,2,3,4,5,6$ as shown in the picture. The purpose of giving sticks is so that they can be used to attach the contents of the domain members and their codomains and to put sticks wrapped around using origami paper so they don't fall off because the sticks are used to show the result area. After that, you can decorate it using the leftover origami paper to make it more interesting and not boring.

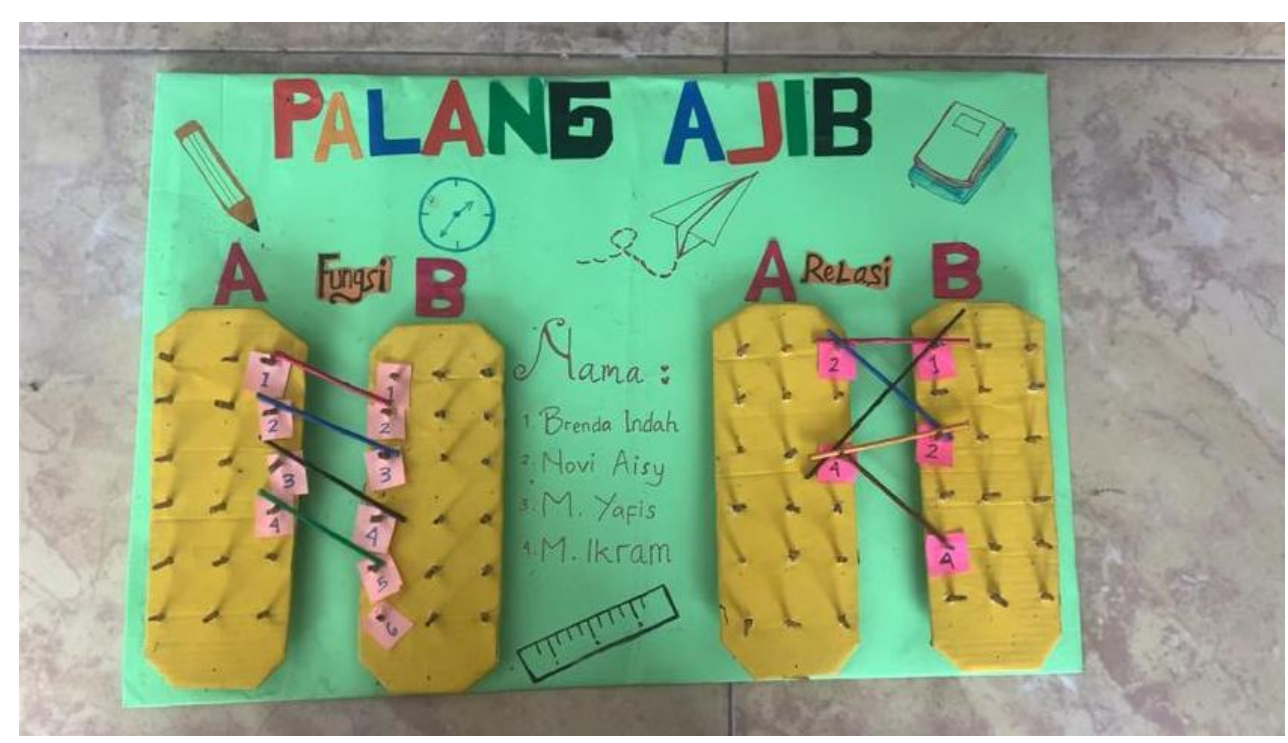

Figure 1. Media Palang ajib

\section{Procedure for Using Palang ajib Media}


For the procedure for using this Papan Langka Ajaib (palang ajib), first write down the "items" in the domain and codomain according to your needs/desires, if it has been written, prepare a folded stick or skewer and make a statement on the blackboard to connect the items. is in the domain and codomain, why should it be written on the blackboard, so that students understand which one to connect.

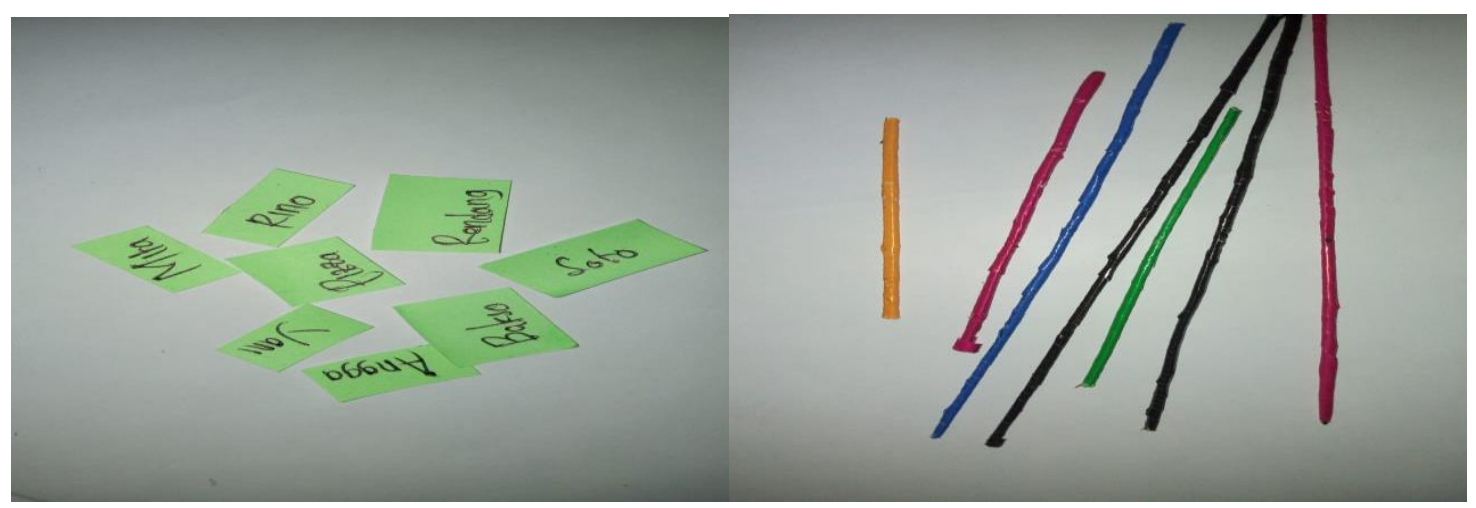

Figure 2. Item domain, range Codomain

Next, connect the items in the domain and codomain using threads and according to the statements on the board. After everything is connected the teacher must explain what types of relations and functions have been made on the Papan Langka Ajaib (palang ajib) or the teacher can also ask questions about the same thing to students to find out the extent of students' knowledge about relations and functions.

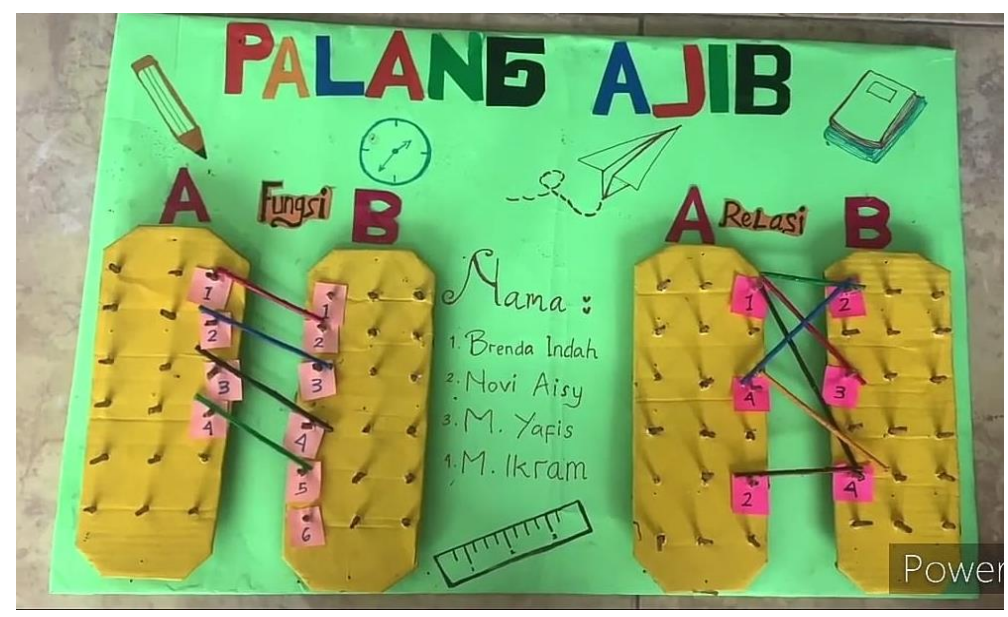

Figure 3. Media crossbar is great in solving problems

This Papan Langka Ajaib (Palang ajib) is a medium intended for junior high school (SMP) students, to be precise in grade 8 or grade 2 in junior high school where the basic competence 
is to describe and state relations and functions using various representations of words, tables, graphs, diagrams, and equations. Where Domain is the origin area, Codomain is the friend area, while the range is the result of the equalization between the main and the codomain. So using this palang ajib media you can determine relations and functions as in the example below.

With the media in the form of a Papan Langka Ajaib (palang ajib) it can be easy in terms of realizing the form of relations and functions, actually without having to make this media you can just describe it but it will feel boring so it can be developed into this form of media so that students who are studying learning is not bored and attracts attention so that students are happy to learn and are more enthusiastic so that learning objectives can be conveyed properly. In addition, it is hoped that this media will also be made so that students can easily find concepts and differences in relations and functions through the application of this Papan Langka Ajaib (palang ajib) media without any problems.

\section{CONCLUSION}

Media is used to support the teaching and learning process so that it is easy and efficient. Media palang ajib is made to help make it easier to understand the material relations and functions. The role of the palang ajib media is intended to help students understand the relation and function material to make it easier to understand. The relationship between the learning media of this palang ajib and the relation and function material is interconnected where this palang ajib is made to be able to easily find which one is a relation and which one is a function.

\section{REFERENCES}

Aspar, M., Mujtaba, I., Mutiarani, \& Putri, S. A. D. (2020). Pemanfaatan Media Pembelajaran Ular Tangga dalam Meningkatkan Semangat Belajar Siswa. Seminar Nasional Pengabdian Masyarakat LPPM UMJ. http://jurnal.umj.ac.id/index.php/semnaskat Badriyah. (2015). Efektifitas Proses Pembelajaran Dengan Pemanfaatan Media Pembelajaran. Jurnal Lentera Komunikasi, 1(1).

Cahyadi, R. A. H. (2019). Pengembangan Bahan Ajar Berbasis ADDIE Model. HALAQA: Islamic Education Journal, 3(1). 
Fauziah, N. (2013). Penggunaan Media Bahan Alam Untuk Meningkatkan Kreativitas Anak. Jurnal IImiah VISI P2TK PAUD NI, 8(1).

Hada, K. L., Maulida, F. I., Dewi, A. S., Dewanti, C. K., \& Surur, A. M. (2021). Pengembangan Media Pembelajaran Blabak Trarerodi pada Materi Geometri Transformasi: Tahap Expert Review. Jurnal Pendidikan Matematika, 4(2), 155-178.

Herawati, A. S. (2014). Konstruksi Konsep Relasi Dan Fungsi Dalam Sistem Gui Matlab. Prosiding Seminar Nasional Matematika.

Januszewski, A., \& Molenda, M. (2008). Technology: A Definition With Commentary. New York: Lawrence Erlbaum Associates.

Mahnun, N. (2012). Media Pembelajaran (Kajian terhadap Langkah-langkah Pemilihan Media dan Implementasinya dalam Pembelajaran). Jurnal Pemikiran Islam, 37(1). Miftah, M. (2013). Fungsi dan Peran Media Pembelajaran Sebagai Upaya Peningkatan Kemampuan Belajar Siswa. Jurnal KWANGSAN, 1(2).

Muhammad, D. D. (2017). Belajar Dan Pembelajaran. Fitrah: Jurnal Kajian IImu-IImu Keislaman, 3(2).

Munirah. (2018). Peranan Guru dalam Mengatasi Kesulitan Belajar Siswa. Jurnal Tarbawi, $3(2)$.

Narulita, D., \& Masduki. (2016). Kesulitan Siswa Dalam Menyelesaikan Masalah Fungsi. Konferensi Nasional Penelitian Matematika Dan Pembelajarannya (KNPMP I).

Nurrita, T. (2018). Pengembangan Media Pembelajaran Untuk Meningkatkan Hasil Belajar Siswa. Misykat, 3(1).

Pane, A. (2017). Belajar Dan Pembelajaran. Fitrah: Jurnal Kajian IImu-IImu Keislaman, 3(2).

Richey, R. C., \& Klein, J. (2007). Design and Development Research: Methods, Strategies, and Issues. Lawrence Erlbaum Associates, Publishers.

Sugiyono. (2014). Metode Penelitian Kuantitatif, Kualitatif, dan R\&D. Alfabeta.

Supriadi. (2015). Pemanfaatan Sumber Belajar Dalam Proses Pembelajaran. Lantanida Journal, 3(2).

Surur, A. M. (2020). Thorndike's Learning Theory Application for Improving Creative Thinking Abilities And Publications. The Atlantis Press Proceedings.

Surur, A. M. (2021). Pengembangan Media Pembelajaran. K-Media.

Surur, A. M., Wahyudi, M. E., \& Mahendra, M. A. (2020). Upaya Meningkatkan Motivasi 
Belajar Siswa Melalui Metode Artikulasi Sebagai Perangsang Timbulnya Kompetensi. Factor M: Focus ACTion Of Research Mathematic, 2(2), 141-156.

Tafonao, T. (2018). Peranan Media Pembelajaran Dalam Meningkatkan Minat Belajar Mahasiswa. Jurnal Komunikasi Pendidikan, 2(2). 